\title{
Editorial
}

\section{Endometrial Cancer in Brazil: Preparing for the Rising Incidence}

\section{Câncer de endométrio no Brasil: preparando-se para o aumento da incidência}

\author{
Eduardo Paulino ${ }^{1,2,3}$ Angélica Nogueira-Rodrigues ${ }^{1,4}$ Paul E. Goss ${ }^{1}$ Lilian Faroni ${ }^{2,3}$ \\ Gustavo Guitmann ${ }^{2}$ Kathrin Strasser-Weippl ${ }^{5}$ Alexandra Bukowski ${ }^{1}$ \\ ${ }^{1}$ Global Cancer Institute, Boston, Masachussets, United States \\ 2 Americas Centro de Oncologia Integrado, Rio de Janeiro, RJ, Brazil \\ 3 Instituto Nacional de Câncer, Rio de Janeiro, RJ, Brazil \\ 4 Universidade Federal de Minas Gerais, Belo Horizonte, MG, Brazil \\ ${ }^{5}$ Wilhelminen Hospital, Vienna, Austria
}

Rev Bras Ginecol Obstet 2018;40:577-579.

Brazil has a population of over 206 million people. ${ }^{1}$ It is estimated that there will be 6.22 new cases of endometrial cancer (EC) for every 100,000 Brazilian women in $2018 .^{2}$ From the estimated 6,000 cases in 2016, GLOBOCAN predicts an increase to 9,372 new cases in 2025 and to 11,963 in $2035^{3}{ }^{3}$

Obesity and overweight are well recognized, important risk factors for EC. ${ }^{4-7}$ Data from the Brazilian Institute of Geography and Statistics (IBGE, in the Portuguese acronym) show that, in the past 5 decades, the percentage of women $>20$ years old who are overweight or obese increased from 29 to $48 \%$ and from 8 to $17 \%$, respectively. ${ }^{8-10}$ These trends will only worsen over time, as the IBGE predicts that $38.2 \%$ of Brazilian women will be obese by 2022.

Older age is another important risk factor, with $\sim 75 \%$ of the patients with type I EC (mainly endometrioid histology) being postmenopausal. ${ }^{11}$ According to the IBGE, the estimated life expectancy in Brazil increased by almost 5 years in the past 15 years, from 73.9 in 2000 to 78.8 years in $2014,{ }^{12}$ with an estimated life expectancy of more than 80 years by $2023 .^{13,14}$

Surgery for EC should be performed by dedicated gynecologic oncologists ${ }^{15}$ because oncological outcomes improve when EC surgical procedures are performed by high-volume surgeons and in high-volume centers. ${ }^{16}$ However, other than in the USA, in the UK or in Germany, where gynecologic oncology is a subspecialty of its own that requires $3+$ years of formal training, there is no society of gynecologic oncology in Brazil, and subspecialty training of 1 to 2 years is offered in only a few institutions. In addition, $>70 \%$ of the Brazilian population are covered by the public health system ${ }^{17}$ and have difficulty accessing specialized institutions. Therefore, typically, general gynecologists or surgeons perform gyneco-oncologic surgery.

Two major randomized trials comparing minimally invasive surgery (MIS) through laparoscopy to traditional open hysterectomy ${ }^{18,19}$ for the treatment of EC showed the benefits of MIS in terms of morbidity without compromising the oncologic outcomes. Despite a lack of formal data, based on other studies in low and middle-income countries (LMICs), ${ }^{20}$ it is reasonable to deduct that Brazilian public hospitals lack laparoscopic devices and the capacity to treat all eligible EC patients in the public healthcare system with MIS. Apart from the lack of infrastructure, the availability of MIS also depends on the medical training of the surgeon, which is often insufficient, as discussed above.

Another minimally invasive procedure is robotic surgery. The US Food and Drug Administration (FDA) approved robotassisted management for gynecologic cancer in 2005 and, in 2009, a survey among the members of the US Society of Gynecologic Oncologists (SGO) revealed that $27 \%$ of the responders had performed robotic-assisted surgery, and $66 \%$ planned to increase their use of it. ${ }^{21}$ The first Brazilian public robotic platform, the da Vinci Xi Surgical System (Strattner, Rio de Janeiro, RJ, Brazil). was implemented in the Brazilian National Cancer Institute (INCA, in the Portuguese acronym) in 2012. As of June 2018, $~ 39$ robotic systems had been installed in Brazil. It is worth emphasizing that only 4 of these 39 robotic platforms were operating in public hospitals. ${ }^{22}$

Most EC cases are diagnosed at an early stage, and international guidelines recommend adjuvant pelvic radiation or brachytherapy, depending on the risk of recurrence. ${ }^{23,24}$ In 2013, the INCA and the Brazilian Society of Radiotherapy (SBR, in the Portuguese acronym) estimated a shortage of 135 machines and $\sim 90,000$ patients per year not receiving radiation therapy despite its indication. ${ }^{25}$ Overall, the public healthcare sector covers only $69.5 \%$ of the need for radiotherapy in Brazil, and there are some states with coverage of less than $50 \% .{ }^{25}$ Based on recommendations of the Brazilian government in 2014 (1 teletherapy machine per 500,000 inhabitants), ${ }^{26} \sim 412$ machines would be needed to cover the entire
Address for correspondence Eduardo Paulino, MD, Rua Equador, 831, 2020-410, Rio de Janeiro, RJ, Brazil

(e-mail: dudupaulino@globo.com).
DOI https://doi.org/ $10.1055 / \mathrm{s}-0038-1673644$. ISSN 0100-7203.
Copyright $\odot 2018$ by Thieme Revinter Publicações Ltda, Rio de Janeiro, Brazil

\section{License terms}

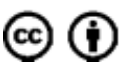


Brazilian population of 206 million. However, as of 2016, only 292 specialized radiotherapy centers were available for the whole country, of which 223 were in the public system. ${ }^{27}$ This deficit translates into lack of treatment and into an overload of the institutions that have radiotherapy machines, resulting in a median delay in the initiation of treatment of 113.4 days (almost 4 months). ${ }^{25}$ In a recent report, it was estimated that 111,432 patients who required radiotherapy in 2016 did not receive this treatment, and that over 5,000 deaths would probably have been prevented in the cases of the most common cancer types if radiotherapy access were universal in the Brazilian Public Health System (SUS, in the Portuguese acronym). ${ }^{28,29}$ There is room for improvement in three major areas when it comes to EC care and control in Brazil:

1. Increase the number of radiotherapy machines. In $2012,{ }^{27}$ the federal government planned to increase its radiotherapy services, adding 80 linear accelerators by 2015 (32 machines to centers with existing radiotherapy services, and 48 to new centers). ${ }^{30}$ As of April 2017, however, the last bulletin from the Ministry of Health showed that only 10 centers have initiated this expansion, only 1 machine has been installed, and 6 centers had subsequently been excluded from the plan. ${ }^{30}$ With a timeframe of $\sim 30$ months between the building of the bunker and the beginning of operations of the system, it is urgent to make progress as soon as possible.

2. Improve training and expertise of gyneco-oncologists. It is necessary to expand training programs for radio-oncologists and to promote specialized training in gynecologic oncology, specifically in performing MIS. Oncological surgeons in Brazil have expressed willingness to create a gynecologic oncology subspecialty in the country, which would certainly improve clinical readiness to deal with EC cases.

3. Support prevention strategies. Recently, the INCA launched national recommendations on healthy nutrition and exercise to educate the population about the risks of a sedentary lifestyle and poor eating habits and their relation to cancer. ${ }^{31}$ Concerted efforts now need to be made to ensure that these measures of primary prevention reach the general public.

The incidence of EC is rising in both high and middleincome countries due to an increase in Westernized lifestyles, to the rates of overweight and obesity, and to a higher life expectancy. Brazil will face a sharp increase in EC cases in the next decade, which will exacerbate the current shortages and barriers in the treatment of EC. It is therefore imperative to implement EC prevention policies, improve radiotherapy resources, and augment equitable patient access to specialized and well-equipped cancer centers with trained professionals.

\section{References}

1 Instituto Brasileiro de Geografia e Estatística. Diretoria de Pesquisas. Coordenação de População e Indicadores Sociais. Estimativas da População Residente para os Municípios e para as Unidades da Federação Brasileiros com Data de Referência em $1^{\circ}$ de Julho de 2016.2016ftp://ftp.ibge.gov.br/Estimativas_de_ Populacao/Estimativas_2016/estimativa_dou_2016_20160913. pdf. Accessed November 2, 2016.
2 Ministério da Saúde. Instituto Nacional de Câncer José Alencar Gomes da Silva. Coordenação de Prevenção e Vigilância. Estimativa 2018: Incidência de Câncer no Brasil. Rio de Janeiro, RJ: INCA; 2018http://www.inca.gov.br/estimativa/2018/casos-taxas-brasil.asp. Accessed August 23, 2018.

3 International Agency for Research on Cancer. GLOBOCAN 2012: Cancer Incidence, Mortality and Prevalence Worldwide. Lyon: IARC; 2012http://globocan.iarc.fr/old/burden.asp?selection_pop $=24076 \&$ Text-p $=$ Brazil\&selection_cancer $=6172 \&$ Text- $\mathrm{c}=$ Corpus + uteri\&pYear $=23 \&$ type $=0 \&$ window $=1 \&$ submit $=\%$ C2\%A0 Execute $\%$ C2\%A0. Accessed November 2, 2016.

4 Renehan AG, Tyson M, Egger M, Heller RF, Zwahlen M. Body-mass index and incidence of cancer: a systematic review and metaanalysis of prospective observational studies. Lancet 2008;371 (9612):569-578 Doi: 10.1016/S0140-6736(08)60269-X

5 Bianchini F, Kaaks R, Vainio H. Overweight, obesity, and cancer risk. Lancet Oncol 2002;3(09):565-574 Doi: 10.1016/S1470-2045 (02)00849-5

6 Reeves GK, Pirie K, Beral V, Green J, Spencer E, Bull D; Million Women Study Collaboration. Cancer incidence and mortality in relation to body mass index in the Million Women Study: cohort study. BMJ 2007;335(7630):1134 Doi: 10.1136/bmj.39367.495995.AE

7 von Gruenigen VE, Gil KM, Frasure HE, Jenison EL, Hopkins MP. The impact of obesity and age on quality of life in gynecologic surgery. Am J Obstet Gynecol 2005;193(04):1369-1375 Doi: 10.1016/j.ajog.2005.03.038

8 Ministério da Saúde. Departamento de Atenção Básica. Estudo Nacional de Despesas Familiares (ENDEF-1977). http://dab.saude. gov.br/portaldab/ape_vigilancia_alimentar.php?conteudo=endef. Accessed November 6, 2016.

9 Instituto Brasileiro de Geografia e Estatística. Diretoria de Pesquisas. Coordenação de Trabalho e Rendimento. Pesquisa de Orçamentos Familiares 2002-2003: Antropometria e Estado Nutricional de Crianças, Adolescentes e Adultos no Brasil. Rio de Janeiro, RJ: IBGE; 2006https://biblioteca.ibge.gov.br/visualizacao/livros/ liv30326.pdf. Accessed November 6, 2016.

10 Instituto Brasileiro de Geografia e Estatística. Diretoria de Pesquisas. Coordenação de Trabalho e Rendimento. Pesquisa de Orçamentos Familiares 2008-2009: Antropometria e Estado Nutricional de Crianças, Adolescentes e Adultos no Brasil. Rio de Janeiro, RJ: IBGE; 2010http://biblioteca.ibge.gov.br/visualizacao/livros/ liv45419.pdf. Accessed November 6, 2016.

11 Felix AS, Weissfeld JL, Stone RA, et al. Factors associated with Type I and Type II endometrial cancer. Cancer Causes Control 2010;21 (11):1851-1856 Doi: 10.1007/s10552-010-9612-8

12 Instituto Brasileiro de Geografia e Estatística. Diretoria de Pesquisas. Coordenação de População e Indicadores Sociais. Tábua Completa de Mortalidade para o Brasil - 2014: Breve Análise da Evolução da Mortalidade no Brasil. Rio de Janeiro, RJ: IBGE; 2015ftp://ftp.ibge.gov.br/Tabuas_Completas_de_Mortalidade/ Tabuas_Completas_de_Mortalidade_2014/notastecnicas.pdf. Accessed November 2, 2016.

13 Instituto Brasileiro de Geografia e Estatística. Censo demográfico 20002002https://ww2.ibge.gov.br/home/presidencia/noticias/ 20122002censo.shtm. Accessed November 2, 2016.

14 Instituto Brasileiro de Geografia e Estatística. Diretoria de Pesquisas. Coordenação de População e Indicadores Sociais. Projeção da População do Brasil por Sexo e Idade para o Período 1980-2050 - Revisão 2008. Rio de Janeiro, RJ: IBGE; 2008http://biblioteca.ibge.gov.br/ visualizacao/livros/liv41229.pdf. Accessed November 2, 2016.

15 Practice Bulletin No. 149: Endometrial cancer. Obstet Gynecol 2015; 125(04):1006-1026 Doi: 10.1097/01.AOG.0000462977.61229.de

16 Díaz-Montes TP, Zahurak ML, Giuntoli RL II, Gardner GJ, Bristow RE. Uterine cancer in Maryland: impact of surgeon case volume and other prognostic factors on short-term mortality. Gynecol Oncol 2006;103(03):1043-1047

17 Instituto Brasileiro de Geografia e Estatística. Coordenação de Trabalho e Rendimento. Pesquisa Nacional de Saúde: 2013: Acesso 
e Utilização dos Serviços de Saúde, Acidentes e Violências: Brasil, Grandes Regiões e Unidades da Federação. Rio de Janeiro, RJ: IBGE; 2015http://biblioteca.ibge.gov.br/visualizacao/livros/liv94074.pdf. Accessed November 2, 2016.

18 Janda M, Gebski V, Brand A, et al. Quality of life after total laparoscopic hysterectomy versus total abdominal hysterectomy for stage I endometrial cancer (LACE): a randomised trial. Lancet Oncol 2010;11(08):772-780 Doi: 10.1016/S1470-2045(10) 70145-5

19 Walker JL, Piedmonte MR, Spirtos NM, et al. Recurrence and survival after random assignment to laparoscopy versus laparotomy for comprehensive surgical staging of uterine cancer: Gynecologic Oncology Group LAP2 Study. J Clin Oncol 2012;30(07):695-700 Doi: $10.1200 / J C O .2011 .38 .8645$

20 Chao TE, Mandigo M, Opoku-Anane J, Maine R. Systematic review of laparoscopic surgery in low- and middle-income countries: benefits, challenges, and strategies. Surg Endosc 2016;30(01): 1-10 Doi: 10.1007/s00464-015-4201-2

21 Averette HE, Wrennick A, Angioli R. History of gynecologic oncology subspecialty. Surg Clin North Am 2001;81(04): 747-751 Doi: 10.1016/S0039-6109(05)70162-6

22 Secin FP, Coelho R, Monzó Gardiner JI, et al. Robotic surgery in public hospitals of Latin-America: a castle of sand? World J Urol 2018;36(04):595-601 Doi: 10.1007/s00345-018-2227-5

23 National Comprehensive Cancer Network. NCCN Guidelines: Uterine Neoplasms. Vol 2. 2018https://www.nccn.org. Accessed August 23, 2018.

24 Colombo N, Creutzberg C, Amant F, et al; ESMO-ESGO-ESTRO Endometrial Consensus Conference Working Group. ESMOESGO-ESTRO Consensus Conference on Endometrial Cancer: diagnosis, treatment and follow-up. Ann Oncol 2016;27(01):16-41 Doi: $10.1093 /$ annonc/mdv484

25 Ferrigno RPanorama da Radioterapia no Brasil. São Paulo, SP: Sociedade Brasileira de Radioterapia; 2013http://www.sbradio- terapia.com.br/pdfs/panorama2013.pdf. Accessed November 2, 2016.

26 Ministério da Saúde. Secretaria de Atenção à Saúde. Portaria N ${ }^{\circ}$ 140, de 27 de fevereiro de 2014. Redefine os critérios e parâmetros para organização, planejamento, monitoramento, controle e avaliação dos estabelecimentos de saúde habilitados na atenção especializada em oncologia e define as condições estruturais, de funcionamento e de recursos humanos para a habilitação destes estabelecimentos no âmbito do Sistema Único de Saúde (SUS). Diário Oficial da União, Brasília, DF. Fevereiro 28, 2014:71 http://www.sgas.saude.ms.gov.br/wp-content/uploads/ sites/105/2016/08/Portaria-140-2014-UNACON.pdf. Accessed November 2, 2016.

27 Ministério da Saúde. Portaria N 931 , de 10 de maio de 2012. Institui o Plano de Expansão da Radioterapia no Sistema Único de Saúde (SUS). Diário Oficial da União, Brasília, DF. Maio 11, 2012:140-141. http://bvsms.saude.gov.br/bvs/saudelegis/gm/2012/prt0931_10_0 5_2012.html. Accessed November 2, 2016.

28 Mendez LC, Moraes FY, Fernandes GDS, Weltman E. Cancer deaths due to lack of universal access to radiotherapy in the Brazilian Public Health System. Clin Oncol (R Coll Radiol) 2018;30(01): e29-e36 Doi: 10.1016/j.clon.2017.09.003

29 Mabrouk M, Frumovitz M, Greer M, et al. Trends in laparoscopic and robotic surgery among gynecologic oncologists: A survey update. Gynecol Oncol 2009;112(03):501-505 Doi: 10.1016/j. ygyno.2008.11.037

30 Ministério da Saúde. Plano de Expansão da Radioterapia no SUS. 2017 http://portalms.saude.gov.br/ciencia-e-tecnologia-e-complexo industrial/complexo-industrial/plano-de-expansao-da-radioterapia-no-sus. Accessed May 8, 2017.

31 Ministério da Saúde. Instituto Nacional de Câncer José Alencar Gomes da Silva. Políticas e Ações para Prevenção do Câncer no Brasil: Alimentação, Nutrição e Atividade Física. Rio de Janeiro, RJ: INCA; 2012 